\title{
BRPKM
}

Buletin Riset Psikologi dan Kesehatan Mental

http://e-journal.unair.ac.id/index.php/BRPKM

e-ISSN: 2776-1851

ARTIKEL PENELITIAN

\section{Hubungan antara Efikasi diri dengan Kecemasan dalam menghadapi Ujian SBMPTN pada Siswa SMA}

\author{
ADELIA EKA LAUDITTA \& ATIKA DIAN ARIANA* \\ Fakultas Psikologi Universitas Airlangga
}

\begin{abstract}
ABSTRAK
Efikasi diri atau self-efficacy adalah keyakinan seseorang pada kemampuannya dalam melakukan suatu bentuk kontrol terhadap keberfungsian kejadian dalam lingkungan dan orang itu sendiri. Individu cenderung akan lari atau memilih menghindari dari situasi yang individu tidak akan mampu untuk mengatasi atau menghadapinya. Penelitian ini mempunyai tujuan untuk mengetahui ada atau tidaknya hubungan antara efikasi diri dengan kecemasan pada siswa yang akan menghadapi Ujian Seleksi Bersama Masuk Perguruan Tinggi Negeri (SBMPTN) pada siswa SMA. Penelitian kuantitatif ini menggunakan metode survei dengan melibatkan 113 responden. Penelitian ini menggunakan alat ukur General Self-Efficacy Scale dan Cognitive Test Anxiety Scale and Academic Performance. Pada penelitian ini hasil uji korelasi menunjukkan 0,166, variabel dapat dikatakan berhubungan apabila nilai signifikansi $p<0,05$ maka hasil menunjukkan bahwa hipotesis penelitian ini ditolak, yang berarti bahwa tidak terdapat hubungan yang signifikan antara efikasi diri dengan kecemasan dalam menghadapi ujian SBMPTN pada siswa SMA.
\end{abstract}

Kata kunci: efikasi diri, kecemasan, siswa sma

\begin{abstract}
Self-efficacy is a person's belief in his ability to exercise some form of control over the functioning of events in the environment and the person himself. Individuals tend to run away or choose to avoid situations that believe they will not to able deal with. This study aims to determine whether or not relationship between Self-efficacy and anxiety in students who will Joint Selection (SBMPTN) in high school students. This quantitative research uses a survey method involving 113 respondents. This study uses the General Self-Efficacy Scale and Cognitive Test Anxiety Scale and Academic Performance. In this study, the results of the correlation test showed 0.166 , the variable can be said to be related if the significance value of $\mathrm{p}<0.05$, the results research hypothesis is rejected, which means that there is no significant relationship between self-efficacy and anxiety in students who will Joint Selection Examination (SBMPTN) in high school students.
\end{abstract}

Keywords: anxiety, self-efficacy, senior high school students

Buletin Penelitian Psikologi dan Kesehatan Mental (BRPKM), 2021, Vol. 1(2), 1246-1252

*Alamat korespondensi: Fakultas Psikologi Universitas Airlangga, Kampus B Universitas Airlangga Jalan

Airlangga 4-6 Surabaya 60286.Surel: atika.ariana@psikologi.unair.ac.id 


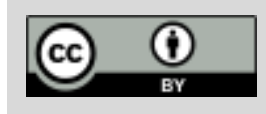

Naskah ini merupakan naskah dengan akses terbuka dibawah ketentuan the Creative Common Attribution License (CC-BY-4.0) (http://creativecommons.org/licenses/by/4.0), sehingga penggunaan, distribusi, reproduksi dalam media apapun atas artikel ini tidak dibatasi, selama sumber aslinya disitir dengan baik.

\section{P E N D A H U L U A N}

Seleksi Bersama Masuk Perguruan Tinggi Negeri (SBMPTN) adalah seleksi masuk PTN melalui jalur tes tulis yaitu UTBK (Ujian Tulis Berbasis Komputer), Peraturan Menteri Riset, Teknologi, dan Pendidikan (Menristekdikti) tentang UTBK menyatakan bahwa UTBK akan diselenggarakan oleh Lembaga Tes Masuk Perguruan Tinggi (LTMPT) dengan sistem yang berbeda yaitu peserta melakukan tes terlebih dahulu, peserta mendapatkan nilai lalu baru mendaftarkan ke Perguruan Tinggi Negeri (PTN) dan menunggu penentuan kelulusan. UTBK tahun 2021 memili syarat yaitu dapat diikuti oleh siswa yang lulus pada tahun 2019, 2020, dan 2021 dari pendidikan menengah (SMA/MA/SMK) dan sederajat, serta siswa lulusan paket $C$ tahun 2019, 2020, dan 2021 dengan syarat umur siswa yaitu maksimal 25 tahun. UTBK merupakan syarat utama agar dapat mengikuti SBMPTN yang dilaksanakan secara serentak di 85 PTN se-Indonesia.

Data Kementerian Riset, Teknologi, dan Pendidikan Tinggi bersama dengan Lembaga Tes Masuk Perguruan Tinggi (LTMPT), pendaftar SBMPTN tahun 2019 ada 714.652 peserta (91,53\%), dan jumlah peserta yang dapat dinyatakan lulus seleksi Perguruan Tinggi Negeri (PTN) se-Indonesia sebanyak 168.742 peserta $(23,61 \%)$ dari jumlah pendaftar (Kompas, 2019) . Sementara itu, jumlah pendaftar SBMPTN tahun 2021 ada 777.863 peserta sementara yang dinyatakan lulus sebanyak 184.942 peserta $(23,78 \%)$ (Kompas, 2021). Keketatan seleksi pada SBMPTN dapat memicu dampak pada timbulnya kecemasan siswa yang akan mengikuti ujian SBMPTN. Disisi lain, perubahan pola tes menggunakan 100\% UTBK sejak tahun 2019 dapat menyebabkan rasa canggung terutama bagi siswa yang pertama kali menghadapi ujian dengan model pengujian Computer Based Test (CBT).

Siswa yang tidak terbiasa atau belum terbiasa dalam menghadapi CBT mempunyai resiko lebih tinggi mengalami dampak psikologis berupa kecemasan. Kecemasan dan kegelisahan dalam menjelang ujian serta pada saat proses ujian dapat menyebabkan siswa tidak dapat berkonsentrasi atau fokus dalam mengerjakan tes dengan baik ketika menggunakan ujian berbasis komputer. Mempunyai kemampuan dasar mengoperasikan komputer belum menjadi jaminan bahwa siswa sudah terbiasa dengan model ujian berbasis komputer. Hal itu mengingat bahwa siswa telah terbiasa menggunakan ujian dengan media kertas yang telah berlangsung selama bertahun-tahun, sedangkan sosialisasi ujian dengan menggunakan media komputer baru dilaksanakan dalam waktu beberapa bulan. Kemungkinan akan ada hambatan secara psikologis sehingga dapat mempengaruhi adanya hasil perbedaan dari model pengujian media PBT dan CBT.

Ketidakterbiasaan dalam mengerjakan ujian berbasis media komputer membuat siswa merasa tidak mampu menunjukkan kemampuan terbaiknya pada saat mengerjakan ujian. Faktor kebiasaan siswa dalam mengerjakan soal menggunakan model Paper Based Test (PBT) tanpa disadari mempunyai pengaruh yang kurang mendukung kinerja dalam tes (Suhardi, 2018). Adapun kendala atau hambatan terhadap pelaksanaan ujian tulis berbasis komputer yaitu jaringan yang lambat sehingga memerlukan waktu lebih, gangguan jaringan pada saat cuaca buruk seperti hujan atau hujan petir yang berpeluang terjadi pemadaman listrik pada saat simulasi berlangsung, yang mengakibatkan konsentrasi siswa akan terganggu dan menyebabkan waktu ujian tidak selesai sesuai jadwal atau waktu bertambah, serta

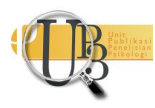


kendala lain adalah server pusat yang kadang bermasalah dan dengan adanya pemberitahuan yang lambat maka pihak yang terlibat menjadi khawatir dengan masalah yang terjadi. Kendala-kendala tersebut akan menganggu pelaksanaan UTBK yang apabila tidak ditangani dengan cepat, dapat menimbulkan rasa kekhawatiran siswa yang berakibat pada konsentrasi siswa dalam mengerjakan soal ujian (Harmiyuni \& Sailan, 2016).

CBT diketahui sebagai salah satu model ujian yang dapat menyebabkan kecemasan yang lebih tinggi pada siswa daripada ujian dengan metode PBT. Dampak kecemasan yang dirasakan oleh seseorang dapat menimbulkan rasa gelisah, khawatir, rasa tidak tentram dikaitkan dengan ancaman baik dari dalam maupun luar diri serta rasa takut yang muncul (Anissa, 2018). Gejala kecemasan terkait CBT yang dialami siswa diantaranya, tidak mampu berkonsentrasi, panik, merasa tidak mampu dan putus asa, kelelahan dan kesulitan pada tidur sebelum tes berlangsung serta tubuh akan berkeringat dan merasa gugup saat ujian berlangsung (Abiantoro, 2019). Kecemasan menyebabkan seseorang kurang fokus dan kurang konsentrasi karena pikiran dari individu tersebut fokus pada hal-hal yang mengantisipasi di masa yang akan datang. Pada siswa, kecemasan bisa menurunkan motivasi dan meningkatkan rasa pesimis atau tidak percaya diri terhadap keyakinan dan kemampuannya dalam mengerjakan soal ujian. Kecemasan adalah bentuk emosi terhadap individu yang berkenaan dengan munculnya perasaan takut dan rasa terancam oleh sesuatu, biasanya dengan objek ancaman yang tidak diketahui begitu jelas sebabnya (Agustiar \& Yuli, 2010). Barlow (dalam Cervone \& Lawrence, 2011) menjelaskan bahwa menurut kognitif sosial, seseorang dengan persepsi atau pikiran terhadap keyakinan diri atau efikasi diri rendah maka akan terancam secara potensial dengan munculnya perasaan cemas yang tinggi. Kejadian tersebut memang tidak terjadi hal yang mengancam, namun perasaan tidak yakin terhadap keyakinan diri sendiri dan kemampuan pada diri sendiri dalam menghadapi serta mengatasi masalah merupakan penyebab awal sumber dalam kecemasan.

Hubungan antara efikasi diri dan tingkat kecemasan pada siswa telah dieksplorasi dalam beberapa penelitian. Penelitian Cubukcu (2008) menemukan bahwa tidak ada hubungan yang signifikan antara efikasi diri dengan kecemasan. Namun penelitian Hidayatin \& Darmawanti (2013) menemukan bahwa efikasi diri dapat mempengaruhi kecemasan siswa apabila efikasi diri dan keyakinan pada diri seseorang semakin tinggi, maka semakin rendah kecemasannya dan sebaliknya. Berdasarkan penelitian yang telah dilakukan oleh Putri dkk. (2017) menjelaskan bahwa siswa yang memiliki keyakinan diri atau efikasi diri yang tinggi akan memiliki kecemasan yang begitu rendah, hal ini disebabkan karena siswa tersebut memiliki keyakinan akan kemampuannya, kepercayaan diri yang tinggi, keyakinan dalam mencapai target yang sudah ditetapkan, dan keyakinan pada kemampuan kognitifnya namun apabila siswa memiliki keyakinan diri atau efikasi diri yang rendah maka akan memiliki kecemasan yang tinggi, hal ini disebabkan karena tidak adanya keyakinan diri atas kemampuan yang dimiliki sehingga mereka tidak merasa adanya percaya diri dalam dirinya, sehingga merasa tidak yakin terhadap kemampuannya, tidak mempunyai target akan nilai dalam ujian tersebut dan rasa tidak yakin pada kemampuannya yang dimiliki.

Kecemasan pada akhirnya dapat disimpulkan sebagai ketakutan terhadap obyek yang tentu tidak jelas sebabnya, muncul suatu perasaan terancam merupakan tanggapan terhadap sesuatu yang sebenarnya tidak mengancam. Jika siswa tidak dapat mengatasi kecemasannya, ia beresiko mengalami gangguan kecemasan. Namun apabila siswa memiliki keyakinan diri atau efikasi diri yang tinggi, ia dapat meyakinkan dirinya bahwa seseorang dapat melakukan tindakan atau mengerjakan tugas yang dibutuhkan untuk mencapai dan menggapai tujuan, demikian pula sebaliknya. Terlihat dari penjelasan yang dijelaskan diatas dan hasil penelitian diatas yang sudah dilakukan, maka peneliti ingin menggali hubungan antara efikasi diri dengan kecemasan dalam menghadapi ujian. 


\section{Desain Penelitian}

\section{E T OD E}

Penelitian ini merupakan tipe penelitian kuantitatif. Pemilihan tipe penelitian kuantitatif ini didasarkan pada tujuan penelitian yakni untuk menguji hipotesis dengan cara memperoleh nilai signifikansi hubungan antar variabel. Desain penelitian kuantitatif ini menggunakan metode survei untuk mengkaji populasi yang besar. Penentuan desain penelitian ini dikarenakan metode survei dapat mengkaji populasi yang besar dengan menggunakan sampel populasi untuk dapat membuat generalisasi terkait karakteristik pada populasi tersebut.

\section{Partisipan}

Partisipan dalam penelitian ini merupakan siswa SMA yang mengikuti ujian SBMPTN. Jumlah sampel dengan rumus: $\mathrm{N}>50+8 \mathrm{~m}$, dimana $\mathrm{n}=$ jumlah sampel; $\mathrm{m}=$ jumlah variabel bebas (Tabachnick \& Fidell, 2007). Variabel bebas berjumlah 1 variabel, maka diketahui jumlah sampel minimal adalah 58 orang.

Teknik sampling yang digunakan adalah purposive sampling dimana pemilihan sampelnya didasarkan pada karakteristik tertentu sesuai tujuan penelitian. Adapun kriteria partisipan dalam penelitian ini terdiri dari: a.) siswa laki-laki dan perempuan; siswa SMA tingkat akhir yaitu kelas XII; dan c.) mengikuti Seleksi Bersama Masuk Perguruan Tinggi Negeri (SBMPTN) UTBK 2021. Proses pengumpulan data dilakukan secara online menggunakan google form sebelum mengisi kuesioner, terdapat informed consent pada halaman awal yang wajib diisi, sehingga tidak terdapat paksaan dalam mengisi kuesioner. Total jumlah responden adalah 113 orang, yaitu 39 siswa laki-laki $(34,5 \%)$ dan 74 siswa perempuan $(65,6 \%)$.

\section{Pengukuran}

Efikasi diri didefinisikan sebagai keyakinan seseorang pada kemampuannya untuk melakukan suatu bentuk kontrol terhadap keberfungsian orang itu sendiri maupun kejadian dalam lingkungan (Bandura, 1997). Instrumen yang digunakan untuk mengukur efikasi diri adalah skala General Self-Efficacy Scale yang telah digunakan oleh peneliti sebelumnya, dimensinya berdasarkan dari teori Bandura (dalam Zimmerman, 2000) yaitu Level, Strength, Generality (Nisa, 2019). Skala Efikasi Diri terdiri dari 40 item dengan 4 pilihan jawaban (1= "sangat sesuai", 4= "sangat tidak sesuai"). Koefisien reliabilitas skala Efikasi Diri pada penelitian sebelumnya adalah 0,747 (Nisa, 2019).

Kecemasan didefinisikan sebagai perasaan afektif yang timbul rasa tidak menyenangkan serta diikuti gejala fisik yang mengingatkan seseorang akan bahaya yang dirasakan dapat mengancam dirinya, (Freud dalam Feist, 2010). Instrumen yang digunakan untuk mengukur kecemasan adalah Cognitive Test Anxiety Scale and Academic Performance yang telah digunakan oleh peneliti sebelumnya, yaitu Lubaba (2018) yang dimensinya disusun berdasarkan aspek kecemasan Deffenbacher dan Hazeleus yang terdiri dari aspek kekhawatiran, emosionalitas dan gangguan serta hambatan dalam menyelesaikan suatu tugas. Skala Kecemasan terdiri dari 26 item dengan 5 pilihan jawaban (1= "sangat sesuai", 5="sangat tidak sesuai"). Koefisien reliabilitas pada skala Kecemasan di penelitian sebelumnya adalah 0,927 (Lubaba, 2018).

\section{Analisis Data}

Teknik analisis data yang digunakan untuk uji hipotesis pada penelitian ini adalah teknik korelasi dari Pearson's Product Moment karena data penelitian telah memenuhi uji asumsi (normalitas dan linearitas). Perangkat lunak yang digunakan untuk menganalisa data penelitian ini adalah SPSS 25 for Windows. 


\section{HAS IL P E N ELIT IAN}

Hasil analisis deskriptif menunjukkan bahwa partisipan memiliki rata-rata skor efikasi diri yang berada pada kategori subthreshold $(\mathrm{N}=113 ; \mathrm{M}=95,50 ; \mathrm{SD}=5,644)$, dan rata-rata skor kecemasan berada pada kategori sedang ( $\mathrm{N}=113 ; \mathrm{M}=81,47 ; \mathrm{SD}=14,430)$.

Hasil analisis uji normalitas Kolmogrov-Smirnov menunjukkan bahwa kedua variabel berdistribusi tidak normal $(p<0,05)$. Data variabel efikasi diri berdistribusi normal setelah dilihat dari rasio kurtosis yang berada pada rentang -2 hingga 2 (rasio kurtosis efikasi diri $=0,42$ ). Data variabel kecemasan dapat dikatakan berdistribusi normal $(p>0,05)$.

Hasil analisis uji linearitas menjelaskan bahwa nilai signifikansi antara variabel efikasi diri dengan kecemasan $(p=0,076)$ yang artinya adalah hubungan kedua variabel tersebut linear. Hasil analisis uji korelasi menunjukkan tidak terdapat hubungan yang signifikan antara efikasi diri dengan kecemasan $(\mathrm{r}(113)=0,166 ; p=0,078)$.

\section{I S K U S I}

Analisis terhadap data penelitian menunjukkan bahwa hipotesis penelitian ditolak, dan menjelaskan bahwa tidak terdapat hubungan yang signifikan antara efikasi diri dengan kecemasan dalam menghadapi ujian SBMPTN pada siswa SMA. Hasil penelitian ini sama dengan penelitian yang dilakukan oleh Cubukcu (2008) yang menemukkan bahwa tidak ada hubungan antara variabel efikasi diri dengan kecemasan dimana tidak terdapat yang signifikan pada tingkat kecemasan dan efikasi diri berdasarkan jenis kelamin. Sejalan dengan ini, penelitian Sari dkk. (2017) menjelaskan bahwa tidak ada perbedaan yang signifikan pada variabel tingkat kecemasan berdasarkan jenis kelamin.

Hipotesis penelitian yang ditolak dapat dijelaskan oleh beberapa faktor, diantaranya adanya faktor lain yang lebih mempengaruhi kecemasan namun tidak diteliti dalam penelitian ini. Penelitian yang dilakukan oleh Hatijah (2018) yang menemukan bahwa hubungan antara efikasi diri dan tingkat kecemasan dimoderasi oleh resiliensi siswa. Sementara itu, penelitian pada Nisa (2019) menunjukkan adanya peran dukungan sosial dalam hubungan antara efikasi diri dan kecemasan siswa menghadapai Ujian Nasional berbasis Komputer (CBT). Siswa yang memiliki dukungan sosial yang tinggi dari orangorang disekitarnya seperti keluarga, teman terdekat, dan orang-orang yang istimewa akan merasa bahwa dirinya diperhatikan dan dicintai sehingga timbulnya rasa cemas yang dialaminya ketika menempuh ujian berlangsung rendah. Begitupun sebaliknya siswa atau murid yang mendapat dukungan sosial yang rendah dari lingkungan terdekatnya akan muncul rasa bahwa dirinya kurang mendapat perhatian, ia merasa dirinya sendiri, timbul perasaan pesimis sehingga seseorang akan mudah putus asa dalam menghadapi masalah dan dapat menimbulkan rasa cemas yang tinggi.

\section{S I M P U L A N}

Berdasarkan penjelasan hasil penelitian ini, dapat disimpulkan bahwa tidak terdapat atau tidak ada dalam hubungan yang signifikan antara masing-masing variabel efikasi diri dengan kecemasan dalam menghadapi ujian pada siswa SMA. Hasil analisis dalam penelitian diatas menjelaskan bahwa hipotesis penelitian ini ditolak, yang artinya bahwa tidak terdapat atau terlihat hubungan yang signifikan antara efikasi diri dengan kecemasan dalam menghadapi ujian SBMPTN pada siswa SMA

Penulis menyadari bahwa penelitian ini tentunya memiliki keterbatasan. Oleh sebab itu penulis mengajukan beberapa saran diantaranya untuk penelitian berikutnya melihat hasil penelitian ini, maka 
masih ada analisa yang harus diteliti lebih lanjut mengenai hubungan antara variabel dalam dimensi self-efficacy dengan kecemasan. Peneliti berikutnya, diharapkan memperhatikan karakteristik siswa yang sesuai serta statistik yang ada dalam penelitian dari penelitian sebelumnya sehingga jika terjadi perbedaan hasil dapat mempersiapkan langsung akibat hasil tidak berkorelasi.

\section{U C A P A N T E R I MAKASIH}

Penulis mengucapkan terima kasih kepada Tuhan Yang Maha Esa atas nikmat dan rahmat yang telah diberikan kepada penulis, kepada dosen pembimbing penulis Ibu Atika Dian Ariana, S.Psi., M.Sc. kepada orang tua penulis, kepada orang terdekat penulis, serta siswa SMA yang mengikuti SBMPTN sudah bersedia menjadi partisipan dalam penelitian ini.

\section{DEKLARASI POTENSI TERJADINYA KONFLIK KEPENTINGAN}

Adelia Eka Lauditta dan Atika Dian Ariana tidak bekerja, menjadi konsultan, memiliki saham, atau menerima dana dari perusahaan atau organisasi manapun yang mungkin akan mengambil untung dari diterbitkannya naskah ini.

\section{PUSTAKA ACUAN}

Abiantoro, M. E. M. (2019). Hubungan Mekanisme Koping dengan Tingkat Kecemasan Menghadapi Computer Based Test (CBT) Mahasiswa Keperawatan Tingkat Pertama Universitas Jenderal Achmad Yani Yogyakarta.

Agustiar, W., \& Yuli, A. (2010). Kecemasan Menghadapi Ujian Nasional dan Motivasi Belajar pada Siswa Kelas XII SMA Negeri “X.” Jurnal Psikologi Volume 8 Nomor 1.

Anissa, L. M. (2018). Tingkat Kecemasan Mahasiswa Keperawatan dalam Menghadapi Ujian Berbasis Computer Based Test. MEDISAINS: Jurnal Ilmiah Ilmu-Ilmu Kesehatan.

Bandura, A. (1997). The anatomy of stages of change. American Journal of Health Promotion : AJHP, 12(1), 8-10. https://doi.org/10.4278/0890-1171-12.1.8

Cervone, D., \& Lawrence, P. (2011). Personality: Theory and Reseach (Twelfth). John Wiley \& Sons, Inc. https://id1lib.org/book/3410753/6e0242

Cubukcu, F. (2008). A Study on the Correlation between Self Efficacy and Foreign Language Learning Anxiety. Journal of Theory and Practice in Education, 4(1), 148-158. http://www.eric.ed.gov/ERICWebPortal/contentdelivery/servlet/ERICServlet?accno=ED502016

Feist, G. J. (2010). The function of personality in creativity: The nature and nurture of the creative personality. In The Cambridge handbook of creativity. (pp. 113-130). Cambridge University Press. https://doi.org/10.1017/CB09780511763205.009

Harmiyuni, \& Sailan, M. (2016). Persepsi Siswa Tentang Pelaksanaan Ujian Nasional Berbasis Komputer di SMK Komputer Mutiara Ilmu Makassar. 41.

Hatijah, S. (2018). Hubungan antara resiliensi dan efikasi diri dengan kecemasan akademik menghadapi ujian nasional pada siswa kelas XII. Fakultas Psikologi Universitas Muhammadiyah Malang.

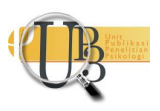


Hidayatin, A., \& Darmawanti, I. (2013). Hubungan Antara Religiusitas Dan Self Efficacy Dengan Kecemasan Menghadapi Ujian Nasional Pada Siswa Kelas XII MAN 1 Model Bojonegoro. Character, 2 Nomor 1.

Kompas. (2019, July 9). Pengumuman SBMPTN 2019: Hanya 23 Persen Berhasil Lulus SBMPTN 2019. https://edukasi.kompas.com/read/2019/07/09/15144981/pengumuman-sbmptn-2019-hanya23-persen-berhasil-lulus-sbmptn-2019?page=all

Kompas. (2021, June 14). Pengumuman LTMPT: 184.942 Peserta Lolos SBMPTN 2021, Ini Rinciannya. https://www.kompas.com/tren/read/2021/06/14/124000665/pengumuman-ltmpt--184.942peserta-lolos-sbmptn-2021-ini-rinciannya?page=all

Lubaba. (2018). Hubungan Antara Dukungan Sosial dengan Kecemasan dalam Menghadapi Ujian pada Peserta Didik Madrasah Aliyah Nahdlatul Ulama Banat Kudus dengan Intensitas Membaca Al-Qur'an sebagai Variabel Moderator. (Skripsi, Universitas Islam Negeri Maulana Malik Ibrahim)

Nisa, N. L. (2019). Hubungan Self-Efficacy dan Dukungan Sosial dengan Kecemasan Siswa Menghadapi Ujian Nasional Berbasis Komputer (CBT) pada Siswa SMK X Kelas XII.

Putri, S. W., Suminta, R. R., \& Handayani, D. (2017). Hubungan Efikasi Diri Dengan Kecemasan Menghadapi Ujian Nasional Pada Siswa. Happiness, 1(2), 111-124.

Sari, A. W., Mudjiran. M., Alizamar, A. (2017). TINGKAT KECEMASAN SISWA DALAM MENGHADAPI UJIAN SEKOLAH DITINJAU dari jurusan yaitu jurusan IPA dan jurusan IPS serta menghadapi US ditinjau dari daerah asal yaitu Minangkabau dan non Minangkabau serta perbedaannya dan ( 4 ) tingkat kecemasan siswa kelamin. Jurnal Bikotetik., 01 (02), 37-72.

Suhardi, I. (2018). Kajian Deskriptif Perbandingan Model Pengujian Paper Based Test dan Computer Based Test (Tinjauan dari Aspek Psikometrik, Konteks dan Suasana, serta Psikologi Pengguna). Jurnal Media Komunikasi Pendidikan Teknologi Dan Kejuruan.

Tabachnick, B. G., \& Fidell, L. S. (2007). Using multivariate statistics (5th ed).

Zimmerman, B. J. (2000). Self-Efficacy: An Essential Motive to Learn. Contemporary Educational Psychology, 25(1), 82-91. https://doi.org/10.1006/ceps.1999.1016 